\title{
In Situ Hybridization for the Detection of Infectious Laryngotracheitis Virus in Sections of Trachea from Experimentally Infected Chickens
}

\author{
By O. L. Nielsen, K.J. Handberg and P. H. Jørgensen \\ Danısh Veterınary Laboratory, Aarhus, Denmark.
}

\begin{abstract}
Nielsen OL, Handberg KJ, Jørgensen PH: In situ hybridization for the detection of infectious laryngotracheitis virus in sections of trachea from experimentally infected chickens. Acta vet. scand. 1998, 39, 415-421. - An in situ hybridization procedure for the detection of infectious laryngotracheitis virus (ILTV) in experimentally infected chickens is described. Formalın-fixed, paraffin-embedded sections of trachea, taken from chickens on days 3-10 post-inoculation (p.1.) with ILTV were hybridized with a mixture of 2 biotinylated, polymerase chain reaction-generated DNA fragments. The fragments correspond to sequences of the ILTV glycoprotein C and thymidine k1nase genes. In situ hybridization was seen in 7 out of 7 chickens examined on day 3 p.1., 2 out of 2 examined on day 4 p.1. and 3 out of 3 examined on day 5 p.1. No hybridization was observed in 3 out of 3 chickens examıned on day 10 p.1. ILTV nucleic acid was detected in nuclei of degenerated tracheal epithelial cells and in intranuclear inclusion bodies of syncytia.
\end{abstract}

\section{Introduction}

Infectious laryngotracheitis (ILT) is an acute infection of the upper respiratory tract of chickens caused by a ds-DNA virus designated Gallid herpes virus 1. ILT has a world-wide distribution, and in the severe form of the disease, infection results in haemorrhagic tracheitis and high morbidity and mortality (Bagust \& Guy 1997).

The first outbreak of ILT in Denmark was diagnosed in backyard chickens in 1993 (Anon. 1993), and ILT has been diagnosed in 10-15 backyard chicken flocks in each of the following years. In 1996 ILT was diagnosed in Sweden for the first time since 1959 in a small backyard chicken flock, and serological screening for ILTV in backyard flocks revealed widespread subclinical ILTV infections (Engström et al. 1997).
The causative virus has been identified by various methods including isolation by different cultural methods (Hughes \& Jones 1988), ant1gen detecting ELISA (York \& Fahey 1988), demonstration of typical histological lesions (Riddell 1987) and transmission electron microscopy (Van Kammen \& Spradbrow 1976). Nucleic acid based methods have included polymerase chain reaction (Shirley et al. 1990, Williams et al. 1994) and filter hybridization (Keam et al. 1991, Key et al. 1994).

In situ demonstration of ILT virus (ILTV) antigens by immunofluorescence or immunochemistry, using acetone-fixed cell smears or cryostat sections of affected organs, has been described by several authors (Ide 1978, Wilks \& Kogan 1979, Bagust et al. 1986, Guy et al. 
1992, Abbas \& Andreasen, Jr. 1996). However, information on the use of formalin fixation is very limited, and the aim of the present study was to develop an in situ hybridization assay for the detection of ILTV nucleic acid in formalinfixed, paraffin-embedded tissue samples, an assay which could prove useful in pathogenicity studies.

\section{Materials and methods \\ Experimental infections}

Tissue samples of trachea from 20 specified pathogen-free (SPF) White Leghorn chickens (Lohmann Tierzucht, Cuxhaven, Germany) were included in the study. At 7 weeks of age, 13 chickens were inoculated intra-tracheally with $10^{35} \mathrm{ELD}_{50}(0.4 \mathrm{ml}$ homogenate of foetal membranes in allantoic fluid from inoculated SPF-chicken embryos) of the A96 strain of ILTV (Central Veterinary Laboratory, Weybridge, UK). In addition, 2 chickens were inoculated intra-tracheally with $10^{25} \mathrm{ELD}_{50}(0.4 \mathrm{ml}$ homogenate) of a Danish ILTV field isolate (94-83949). Four chickens, which served as non-infected controls, were mock-1nfected intra-tracheally with $0.4 \mathrm{ml}$ homogenate from non-1noculated chicken embryos. One additional control chicken was inoculated intra-tracheally with $0.2 \mathrm{ml}$ of the $\mathrm{H} 52$ strain of infectous bronchitis (IB) virus $\left(10^{67} \mathrm{ELD} / \mathrm{ml}\right)$ at the age of 8 weeks. The chickens were kept under positive pressure in isolators supplied with sterile filtered air.

From the group of chickens inoculated with the A96 strain of ILTV, tracheal tissue samples were taken from 3 dead chickens and 2 chickens killed on day 3 post-inoculation (p.i.), from 2 dead chickens on day 4 p.i., and from 3 chickens killed on day 5 p.i. Tracheal tissue and serum were taken from 3 chickens killed on day 10 p.i. From the 2 chickens inoculated with the Danish field isolate, tracheal tissue was taken from one dead chicken and one chicken killed on day 3 p.i. The mock-infected chickens were killed and tracheal tissue taken from one chicken on day 3 p.i. and from 3 chickens on day 5 p.i. The IB virus inoculated chicken was killed on day 1 p.i. and tracheal tissue collected.

\section{ILTV-specific probe}

The ILTV specific probe was prepared as a mixture of 2 biotinylated DNA fragments, generated by polymerase chain reaction (PCR) on DNA extracted from the allantoic fluid of embryonated eggs inoculated with a Danish ILTV field isolate (95-78930). Extraction was performed according to Sambrook et al. (1989). Briefly, $900 \mu \mathrm{l}$ of allanto1c fluid, $100 \mu \mathrm{l}$ buffer (0.1 M Tris. $\mathrm{HCl}$ pH 7.8, $0.05 \mathrm{M}$ EDTA, 5\% SDS $)$ and $10 \mu \mathrm{l}$ of Proteinase $\mathrm{K}(20 \mathrm{mg} / \mathrm{ml})$ was incubated overnight at $55^{\circ} \mathrm{C}$. One volume (vol.) of buffered phenol was added, and after mixıng and centrifugation, the water phase was transferred to new tubes. Subsequently, one vol. of phenol:chloroform:IAA $(25: 24: 1)$ was added, mixing and centrifugation repeated, the water phase transferred to new tubes, and 1:10 vol. of $3 \mathrm{M}$ sodium acetate $\mathrm{pH} 5.2$ and 7:10 vol. of isopropanol added. The DNA was centrifuged (13,000 rpm for $30 \mathrm{~min}$ ) and the pellet was washed in $70 \%$ ethanol, dried and redissolved in $200 \mu \mathrm{l}$ TE.

Two sets of primers were used:

gC-1 (TTTCGAGGGCAGCTCGGTGACCC) and gC-2 (CCATGTACCCAGCGCAGCAGATG); tk-2 (CAAGTGCCACGCTCTTAAAATTC) and tk-3 (AGGATGCGGAACATTACGAACCC).

These correspond to the sequences of the genes encoding glycoprotein $\mathrm{C}(\mathrm{gC})$ (Genbank accession U 06635) and thymidine kinase $(t k)$ (Genbank accession L 36139) from ILTV and were used to amplify fragments of $510 \mathrm{bp}$ and 460 $\mathrm{bp}$, respectively. The primers were originally designed for the detection of ILTV by PCR (results not shown), and the $g C$ and the $t k$ genes 
were chosen because their sequences are known for both ILTV and for all 3 serotypes (1,2 and 3) of Marek's Disease virus (MDV). MDV is, like ILTV, an alpha herpes virus, and infections, either by natural route (serotype 1 and 2) or by vaccination (serotype 1,2 and 3), are common in chickens. Consequently, the $\mathrm{gC}$ primers were selected by alignment to fit the ILTV $g C$ gene (one sequence published) and to show only non-significant homology with the MDV $g C$ genes, and the tk primers were selected to fit all 3 published ILTV $t k$ gene sequences and to exclude the MDV $t k$ genes and the $t k$ gene of the chicken genome. Specificity was further secured by a BLAST search in GenBank.

The PCR amplifications were carried out by mixing the purified DNA with the PCR buffer (x10-stock PCR buffer: $100 \mathrm{mM}$ Tris. $\mathrm{HCl} \mathrm{pH}$ $9.0,15 \mathrm{mM} \mathrm{MgCl}_{2}, 500 \mathrm{mM} \mathrm{KCl}, 1 \%$ Triton X$100,0.1 \%$ gelatin), supplemented with dNTP ( 2 mM each of dATP, dCTP, dGTP, dTTP), 10 mM DTT, $2 \mu \mathrm{M}$ of each primer and 2.5 units of superTAQ (H.T. Biotechnology, Cambridge, $\mathrm{UK})$, to a final volume of $50 \mu \mathrm{l}$. All tubes, reactants and mixtures were kept on ice until insertion in the thermal cycler. The PCR was performed in an Abacus Thermal Cycler (Hybaid, Teddington, UK) using the following 32 cycles: denaturation $92^{\circ} \mathrm{C}$ for $30 \mathrm{~s}$ (cycle no. 1 for 300 s); annealıng $g C: 72^{\circ} \mathrm{C}-58^{\circ} \mathrm{C}$ or tk: $72^{\circ} \mathrm{C}-$ $54^{\circ} \mathrm{C}$ for $30 \mathrm{~s}$ (linear decrease in temperature from cycles nos. 2-25); extension $72^{\circ} \mathrm{C}$ for $60 \mathrm{~s}$ (cycle no. 32 for $300 \mathrm{~s}$ ).

The PCR generated fragments were purified in a QIAquick PCR Spin Column (Qiagen) and biotinylated by random priming with the BioPrime kit (Gibco BRL) according to the manufacturer's instructions.

\section{In situ hybridization}

The tissue samples were fixed for $24 \mathrm{~h}$ in $10 \%$ neutral buffered formalin, embedded in paraffin wax, cut in 3-5 $\mu \mathrm{m}$ thick sections, mounted on
SuperFrost Plus slides (Gerhard Menzle, Braunschweig, Germany), dewaxed in paraffin, and rehydrated. The sections were pretreated by microwave heating to increase the hybridization efficiency (Lan et al. 1996). Briefly, a slide rack containing 20 slides was placed in a Coplin jar, and $0.1 \mathrm{M}$ sodium citrate buffer, $\mathrm{pH} 6.0$, was added up to the $300 \mathrm{ml}$ level mark. A $910 \mathrm{~W}$ power output was then applied for $5 \mathrm{~min}$ followed by a refill with buffer to the original 300 $\mathrm{ml}$ mark. This heating procedure was repeated 3 times followed by $2 \times 5 \mathrm{~min}$ washes in tris buffered saline (TBS).

The tissue sections were then post-fixed in $6 \%$ neutral buffered paraformaldehyde for $15 \mathrm{~min}$, washed in water for $3 \times 1 \mathrm{~min}$ and prehybridized (cover-slip, moist chamber) for $3 \mathrm{~h}$ at $56^{\circ} \mathrm{C}$ with $0.9 \mathrm{mg} / \mathrm{ml}$ sonicated, denatured ( $5 \mathrm{~min}$ at $\left.95^{\circ} \mathrm{C}\right)$ and quenched $\left(5 \mathrm{~min}\right.$ at $\left.0^{\circ} \mathrm{C}\right)$ salmon sperm DNA (Sigma cat. no. D 7656, St. Louis, MO, USA) in $\times 5.5 \mathrm{SSC}, 41 \%$ formamide and $\times 4.5$ Denhardt's solution.

Hybridization was performed overnight (coverslip, moist chamber) at $56^{\circ} \mathrm{C}$ with a mixture of the 2 biotınylated, ILTV specific DNA fragments, each at a concentration of $2 \mathrm{ng} / \mu \mathrm{l}$. The hybridization buffer contained $0.9 \mathrm{mg} / \mathrm{ml}$ sonicated, denatured and quenched salmon sperm DNA, $9 \%$ dextran sulphate, $\times 4.4$ SSC, $33 \%$ formamide and $\times 3.6$ Denhardt's solution. After application of the probe, and prior to incubation, the tissue sections were denatured and quenched for $3 \mathrm{~min}$ at $95^{\circ} \mathrm{C}$ and $0{ }^{\circ} \mathrm{C}$, respectively.

Hybridization was followed by stringencywashing for $4 \times 10 \mathrm{~min}$ in $\times 2 \mathrm{SSC}$ at $20^{\circ} \mathrm{C}, 2 \times 30$ min in $\times 0.5$ SSC with $0.1 \%$ Triton $\mathrm{X}-100$ at $50^{\circ} \mathrm{C}, 2 \times 15 \mathrm{~min}$ in $\times 0.5 \mathrm{SSC}$ at $50^{\circ} \mathrm{C}$, and for $4 \times 10$ min in $\times 2 \mathrm{SSC}$ at $20^{\circ} \mathrm{C}$.

The tissue sections were then washed in TBS with $1 \%$ bovine serum albumin (BSA) and $0.1 \%$ Triton X-100 at room temperature for 30 min, incubated for $1 \mathrm{~h}$ with a $1 / 200$ dilution 


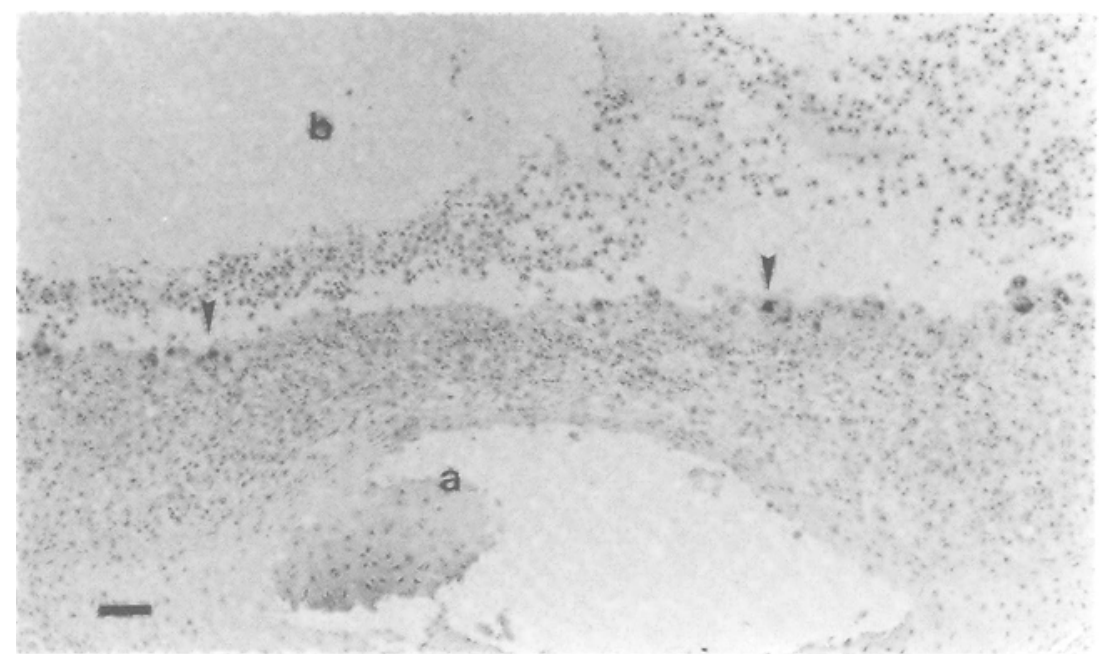

Figure 1 In situ hybridization of ILTV in tracheal epıthelium from a chicken with experımental ILTV infection. Tissue section reacted with the biotinylated ILTV specific probe. Positive stainıng locates to the tracheal epithelium ( $>$ ). Partial detachment of tracheal cartılage durıng the stainıng procedure (a), lumen (b). Counter stained with Meyers haematoxylin. Bar $=50 \mu \mathrm{m}$.

(TBS/1\% BSA/0.1\% Triton X-100) of alkaline phosphatase conjugated streptavidin (DAKO, code D 0396, Glostrup, Denmark), reacted with the substrate New Fuchsin (DAKO, code K 0698, Glostrup, Denmark) for $30 \mathrm{~min}$, counter stained with Meyers haematoxylin, and finally mounted with aqueous mountıng medium.

All tissue sections were hybridized with the ILTV specific probe prepared as a mixture of the 2 biotinylated DNA fragments. In addition, duplicates were hybridized with identical concentrations of a biotinylated chicken anaemia virus-specific probe (Nielsen et al. 1995) in order to monitor the non-specific background staining.

\section{Serological assay}

Sera from the 3 chickens killed on day 10 p.i. were analysed for the presence of anti-ILTV antibodies by means of a commercial ELISA kit (Kirkegaard \& Perry Laboratories, Maryland, USA).

\section{Results}

Tracheal sections from the 12 chickens inoculated with ILTV (either the A96 strain or the Danish field isolate) examıned on days 3-5 p.i. all showed histological lesions characteristic of ILT (Riddell 1987), i.e. acute tracheitis and formation of syncytia of tracheal epithelial cells containing intranuclear inclusion bodies. The syncytia were either located in the epithelium or were lying in the tracheal lumen. In addition, various degrees of degeneration, desquamation and necrosis of the tracheal epithelium, and exudation of neutrophils and bleeding, were observed.

Positive in situ hybridization, identified as precipitated New Fuchsin dye, was detected in the tracheal epithelium (Fig. 1), and was present in 7 out of 7 chickens examined on day 3 p.i. (5 inoculated with the A96 strain and 2 inoculated with the Danish field isolate), 2 out of 2 examined on day 4 p.i. (A96 strain) and 3 out of 3 examined on day 5 p.i. (A96 strain). Staining was 


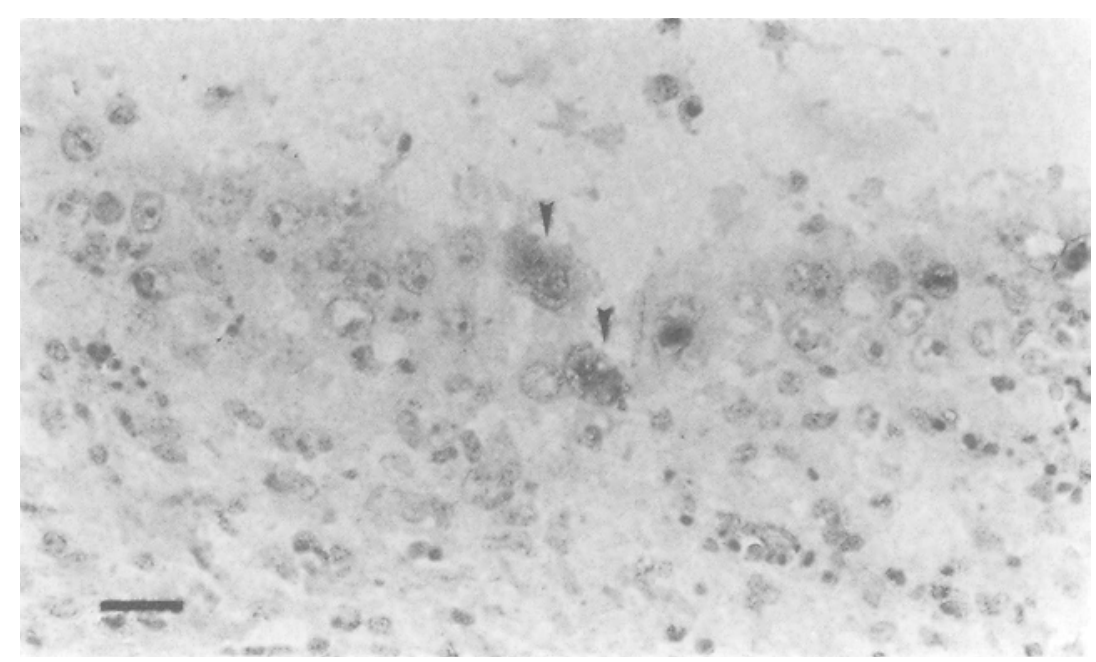

Figure 2. In situ hybridization of ILTV in tracheal epıthelium from a chicken with experimental ILTV infection. Tissue section reacted with the biotinylated ILTV specific probe Weak positive staining locates to nuclei of swollen degenerated epithelial cells $(>)$. Bar $=20 \mu \mathrm{m}$

seen in the nuclei of swollen, degenerated epithelial cells (Fig. 2) and intense staining co-localized with intranuclear inclusion bodies within syncytia (Fig. 3).

The 3 ILTV-inoculated chickens killed on day 10 p.i. (A96 strain) all showed slight epithelial hyperplasia of the tracheal epithelium and a moderate, lichenoid infiltrate with lymphocytes. Positive staining was not seen. All 3 chickens had serum antibodies against ILTV.

No histological lesions were seen in tracheal sections from any of the 4 mock-infected chickens, whereas the chicken inoculated with infectious bronchitis virus showed acute purulent tracheitis. Positive staining was not seen in any of the 5 control chickens. Staining was not seen when the ILTV-specific probe was replaced with the chicken anaemia virus-specific probe.

\section{Discussion}

In situ detection of ILTV antigen by immunofluorescence or immunochemistry in cell smears or cryostat sections from experimentally infected chickens, using acetone fixation, has been described extensively (Ide 1978, Wilks \& Kogan 1979, Bagust et al. 1986, Guy et al. 1992, Abbas \& Andreasen, Jr. 1996). In these studies, ILTV antigen was detected 1-14 days p.i., predominantly 2-8 days p.i. To our knowledge, formalin fixation has previously been described only by Bagust et al. (1986), who detected antigen by immunofluorescence using standard procedures, and by immunofluorescence in formalin fixed duplicates. However, the consequences of formalin fixation were not specified.

The present in situ hybridization procedure could detect ILTV nucleic acid in formalinfixed, paraffin-embedded sections of trachea from 12 out of 12 experimentally infected chickens examined on days 3-5 p.i., while no viral nucleic acid could be detected in 3 chickens on day 10 p.i. The presence of serum antibodies against ILTV in these 3 chickens con- 


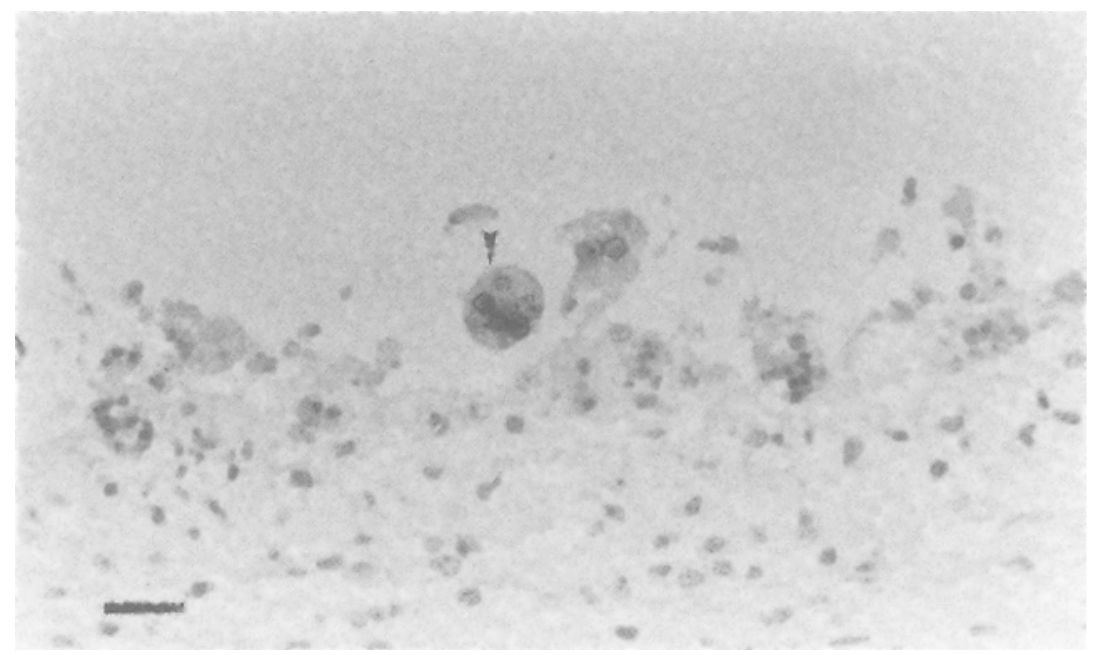

Figure 3. In situ hybridization of ILTV in tracheal epıthelium from a chicken with experimental ILTV infection Tissue section reacted with the biotinylated ILTV specific probe Intense positive staining co-localizes with intranuclear inclusion bodies withın a syncytıum lyıng in the tracheal lumen $(>)$. Bar $=20 \mu \mathrm{m}$

firmed the successful inoculation of the chickens. Thus, the sensitivity of the in situ hybridization assay seems comparable with the sensitivity of the immunofluorescence and immunochemical techniques. Furthermore, detection of ILTV nucleic acid was seen with both the A96 strain and the Danish field isolate of ILTV. Thus, the results fulfill the intention of the present study, i.e. to develop an in situ hybridization assay for the detection of ILTV. The simple demonstration of ILT-typical histological lesions in haematoxylin and eosin stained sections of trachea (Riddell 1987) presents, however, no difficulties and is still preferable for the rapid diagnosis of ILT in field material. Until now, ILT in Sweden (Engström et al. 1997) and in Denmark has been limited to backyard chickens. ILT in the commercial poultry production in other parts of the world was believed to be controlled by vaccination, but ILT has reappeared in broilers, both in European countries and in North America, in recent years (Alexander \& Gough 1997). The ability of ILTV to establish latent infections in the trigeminal ganglion (Bagust et al. 1986) may be responsible for this. Therefore studies of ILT pathogenesis are of current interest, and the hybridization method presented here, which combines detection of ILTV nucle1c acid in situ with the preservation of histological detalls, is a useful tool for such studies.

\section{References}

Abbas F, Andreasen Jr JR Comparison of diagnostic tests for infectious laryngotracheitıs. Avian Diseases, 1996, 40, 290- 295.

Alexander DJ, Gough RE Virus diseases of the respiratory organs. World situation and recent developments Proceedings, XIth International Congress of the World Veterinary Poultry Assoc1ation, 18-22 August, 1997, Budapest, Hungary.

Anonymous The 1993 Annual Report from the Dan1sh National Veterinary Laboratory and State Veterinary Institute for Virus Research

Bagust TJ, Calnek BW, Fahey KJ Gallid-1 herpesvirus infection in the chicken 3. Reinvestigation of the pathogenesis of infectious laryngotracheitıs in acute and early post-acute respiratory disease Avian Diseases, 1986, 30, 179-190. 
Bagust TJ, Guy JS Laryngotracheitıs In: Calnek BW, Barnes HJ, Beard CW, McDougald LR, Saif YM (eds ) D Diseases of poultry 10th Edn. Iowa State University Press, Ames, 1997, 527-539.

Engstròm BE, Renström LHM, Wahlstrom $H$ Transmission of infectious laryngo-tracheitis in backyard chicken in Sweden. Abstract, XIth International Congress of the World Veterinary Poultry Association, 18-22 August, 1997, Budapest, Hungary.

Guy JS, Barnes HJ, Smith LG Rapid diagnosis of infectious laryngotracheitıs using a monoclonal antıbody-based immunoperoxidase procedure. Avian Pathology, 1992, 21, 77-86.

Hughes CS, Jones RC Comparison of cultural methods for primary isolation of infectious laryngotracheitis virus from field material Avian Pathology, 1988, 17, 295-303.

Ide PR Sensitivity and specificity of the fluorescent antibody technique for detection of infectious laryngotracheitıs virus. Canadian Journal of Comparative Medicine, 1978, 42, 54-62.

Keam L, York JJ, Sheppard M, Fahey KJ Detection of infectious laryngotracheitis virus in chickens using a non-radioactive DNA probe. Avian Diseases, 1991, 35, 257-262.

Key DW, Gough BC, Derbyshire JB, Nagy E · Development and evaluation of a non-1sotopically labelled DNA probe for the diagnosis of infectious laryngotracheitis. Avian Diseases, 1994, 38, 467-474.

Lan HY, Mu W, Ng YY, Nikolic-Paterson DJ, Atkıns $R C$ A simple, reliable, and sensitive method for nonradioactive in situ hybridization: Use of microwave heating to improve hybridization efficiency and preserve tissue morphology. The Journal of Histochemistry and Cytochemistry, 1996, 44, 281-287

Nielsen OL, Jørgensen PH, Bisgaard M, Alexandersen $S$ In situ hybridization for the detection of chicken anaemia virus in experımentally-ınduced infection and field outbreaks Avian Pathology, 1995, 24, 149-155.

Riddell C Avian Histopathology. 1st Edn. American Association of Avian Pathologists, University of Pennsylvanıa, 1987.

Sambrook J, Fritsch EF, Manıatıs $T$ Molecular cloning: A laboratory manual. 2nd Edn, Vol. 3. Cold Spring Harbor Laboratory Press, New York, 1989.

Shırley MW, Kemp DJ, Sheppard M, Fahey KJ Detection of DNA from infectious laryngotracheitis virus by colourimetric analysis of polymerase chain reactions. Journal of Virological Methods, 1990, 30, 251-260.

Van Kammen A, Spradbrow PB - Rapid diagnosis of some avian virus diseases. Avian Diseases, 1976, 20, 748-751.

Wilks CR, Kogan VG An immunofluorescence diagnostic test for avian infectious laryngotracheitis Australıan Veterınary Journal, 1979, 55, 385388.

Williams RA, Savage CE, Jones RC. A comparison of direct electron microscopy, virus isolation and a DNA amplification method for the detection of avian infectious laryngotracheitis virus in field material. Avian Pathology, 1994, 23, 709-720.

York JJ, Fahey KJ Diagnosis of infectious laryngotracheitis using a monoclonal antibody ELISA. Avian Pathology, 1988, 17, 173-182.

\section{Sammendrag}

In situ hybridisering af infektıøs laryngotracheitıs virus 1 snit af luftrøret fra eksperimentelt inficerede kyllinger

Udviklıng af en metode tıl in situ hybridisering af infektıøs laryngotracheitıs virus (ILTV) 1 eksper1mentelt inficerede kyllınger beskrıves. Formalın-fikserede, paraffin-indstøbte snit af luftrøret, udtaget fra kyllınger 3-10 dage efter inokulation med ILTV, blev hybridiseret med en blanding af 2 biotınylerede, "polymerase chain reaction" (PCR) baserede DNA fragmenter. De 2 fragmenter repræsenterer generne for henholdsvis viralt glykoprotein $\mathrm{C}$ og tymidin k1nase In situ hybridisering kunne iagttages hos 7 ud af 7 kyllınger undersøgt 3 dage efter inokulation (p 1.), hos 2 ud af 2 kyllınger undersøgt 4 dage $p$ 1. og hos 3 ud af 3 kyllınger undersøgt 5 dage p 13 ud af 3 kyllınger undersøgt 10 dage p.1. var uden hybridiserings-sıgnal ILTV nukleinsyrer sås udelukkende 1 degenererede luftrørs-epithelcelle-kerner og 1 intranucleære inklusionslegemer 1 syncytier.

(Recelved December 11, 1997, accepted June 10, 1998).

Reprınts may be obtained from: O. L. Nielsen, Danısh Veterınary Laboratory, Hangøvej 2, DK-8200 Aarhus N, Denmark E-mall. oln@svs dk, tel: +45 893724 51, fax: +45 89372448 
